\title{
HUBUNGAN AKTIVITAS FISIK DENGAN KEJADIAN OBESITAS PADA ANAK SEKOLAH DI SD MARDI RAHAYU UNGARAN KABUPATEN SEMARANG
}

\author{
Rr. Maghfira Nadia $\mathrm{P}^{1}$, Sri Wahyuni ${ }^{2}$, Sigit Ambar Widiyawati ${ }^{3}$ \\ Program Studi Kesehatan Masyarakat Universitas Ngudi Waluyo, Ungaran \\ E-mail : maghfirafira30@gmail.com
}

\begin{abstract}
ABSTRAK
Masalah Obesitas bukanlah hal baru dalam masyarakat, 30 tahun yang lalu kegemukan merupakan kebanggaan dan lambang dari kesuksesan finansial. Obesitas adalah suatu kelainan akibat penimbunan jaringan lemak tubuh yang berlebihan. Salah satu faktor yang paling mempengaruhi terjadinya obesitas pada seseorang adalah aktivitas fisik. Aktivitas fisik yang dilakukan secara teratur dan terus menerus sesuai umur dan kemampuan akan menurunkan berbagai resiko dan mencegah serta mengurangi lapisan lemak tubuh yang menyebabkan obesitas. Penelitian ini bertujuan untuk mengetahui hubungan antara aktivitas fisik dengan kejadian obesitas pada anak sekolah di SD Mardi Rahayu Ungaran Kabupaten Semarang.Jenis penelitian ini adalah penelitian analitik menggunakan pendekatan cross sectional Populasi dalam penelitian ini adalah anak usia sekolah yang bersekolah di SD Mardi Rahayu Ungaran. Pengumpulan data dilakukan dengan menggunakan timbangan injak, microtoise, dan kuesioner PAQ-C. Pengambilan sampel dilakukan dengan metode purposive sampling dan didapatkan 108 sampel. Teknik analisa data menggunakan uji chi square $\left(x^{2}\right)$. Hasil penelitian menunjukkan bahwa responden yang memiliki aktivitas fisik ringan sebanyak $(34,3 \%)$, sedang $(57,4 \%)$, dan berat $(11,1 \%)$. Responden yang mengalami obesitas sebanyak $(35,2 \%)$ dan tidak obesitas sebanyak $(64,8 \%)$. Hasil uji statistik didapatkan nilai $\mathrm{p}=0,000$ sehingga dapat disimpulkan bahwa ada hubungan antara aktivitas fisik dengan kejadian obesitas pada anak sekolah di SD Mardi Rahayu Ungaran Kabupaten Semarang. Disarankan kepada pihak sekolah sebaiknya mengadakan aktivitas fisik yang bersifat aerobik (lari, renang) dengan intensitas sedang (3 kali seminggu) dan dilakukan secara teratur.
\end{abstract}

\section{Kata Kunci : Obesitas, Aktivitas fisik}

\section{ABSTRACT \\ Correlation between Physical Activities and Obesity in Student SD (Elementary School) Mardi Rahayu Ungaran Semarang Regency}

Obesity in children is a global problem whose numbers increase every year. Obesity is not new in society, 30 years ago obesity was a pride and symbol of financial success. Obesity is a disorder caused by excessive accumulation of body fat tissue. One of the factors that most influence obesity in a person is physical activities. Regular and continuous physical activities according to age and ability will reduce various risks and prevent and reduce the body fat layer that causes obesity. This study aimed to determine the correlation between physical activities and the incidence of obesity in student in SD Mardi Rahayu Ungaran Semarang Regency. This type of research was analytical research using a cross sectional approach, sampling was done by purposive sampling method and obtained 108 samples with inclusion and exclusion criteria. Data collection 
is done by using weight scales, microtoise, and PAQ-C questionnaire. Analysis technique using the chi square test. The respondents who had mild physical activities were $(34,3 \%)$, moderate $(57,4 \%)$, and weighed $(11,1 \%)$. The respondents who were obese were $(35,2 \%)$, and not obese were $(64,8 \%)$. The results of the statistical test obtained p value $=0,000$, so that it can be concluded that there is a correlation between physical activities and incidence of obesity in student in SD Mardi Rahayu Ungaran Semarang Regency. It is recommended that the school should hold physical activities that are aerobic (running, swimming) with moderate intensity (3 times a week) and carried out regularly.

Keywords : Obesity, Physical Activities

\section{PENDAHULUAN}

Sepuluh tahun terakhir, obesitas menjadi masalah global (WHO, 2015). Obesitas pada anak sampai kini masih merupakan masalah, satu dari 10 (sepuluh) anak di dunia mengalami obesitas dan peningkatan obesitas pada anak dan remaja saat ini sejajar dengan orang dewasa. Obesitas pada anak merupakan permasalahan global yang jumlahnya meningkat setiap tahun (WHO, 2013). Obesitas adalah suatu kelainan akibat penimbunan jaringan lemak tubuh yang berlebihan. Penyebab obesitas secara pasti belum jelas, tetapi obesitas pada umumnya diakibatkan oleh ketidakseimbangan antara asupan dan penggunaan energi, dimana asupan lebih besar daripada penggunaan energi. Obesitas disebabkan oleh banyak faktor terutama faktor genetik dan faktor lingkungan. Di negara yang sedang berkembang, faktor lingkungan sangat berperan dalam masalah obesitas. Seperti halnya perubahan pola makan dan kurangnya aktivitas tubuh dalam kehidupan sehari-hari juga sangat menentukan penimbunan lemak di tubuh sehingga mengakibatkan obesitas (Hidayah, 2014).

Dalam The American Journal of Occupational Therapy, di Amerika Serikat, obesitas adalah salah satu faktor resiko yang paling signifikan untuk kesehatan fisik dan psikologis. Masalah seperti gangguan metabolik, diabetes tipe 2, kanker usus besar, penyakit kardivaskuler, kematian dan depresi (Faith sot Matz, \& Jorge; World Media Organization Organizer,2015). Obesitas masa kecil mempengaruhi fungsi motorik yang menyebabkan misalnya penundaan pengembangan motorik dan resiko tinggi untuk mengembangkan kecacatan (Kantomaa et al, 2013)

Seorang dikatakan obesitas apabila Indeks Masa Tubuh (IMT) $\geq 25$ $\mathrm{kg} / \mathrm{m} 2$. Klasifikasi obesitas adalah: kategori I dengan IMT $(\mathrm{kg} / \mathrm{m} 2)$ adalah 25,0-29,9 ; kategori Obesitas II dengan IMT $\geq 30 \mathrm{~kg} / \mathrm{m} 2$. Masalah Obesitas bukanlah hal baru dalam masyarakat, 30tahun yang lalu kegemukan merupakan kebanggaan dan lambang dari kesuksesan finansial. Namun pandangan itu sekarang mulai berubah setalah penelitian-penelitian mendapatkan bahwa hipertensi,obesitas juga merupakan factor resiko penyakit seperti jantung,stroke, dan penyakit pembuluh darah lainya. Oleh karena itu deteksi dini obesitas perlu dilakukan (Dinkes Prov, Jateng 2015). Obesitas bisa terjadi karena perilaku hidup yang tidak sehat, yaitu diet yang tidak seimbang, kurang olah raga atau aktivitas fisik dan pengolahan stress yang tidak akurat (Dinkes Prov Jateng 2014).

Persentase kegemukan pada anak umur 6-11 tahun di Amerika sekitar 15\%. Mengutip data Riset Kesehatan Dasar Kementrian Kesehatan Republik Indonesia pada 
2013, secara nasional masalah gemuk pada anak usia 5-12 tahun masih tinggi yakni $18,8 \%$ terdiri atas gemuk 10,8\% dan sangat gemuk (obesitas) $8,8 \%$. Sedangkan prevalensi gemuk pada remaja usia 13-15 tahun sebesar $10,8 \%$, terdiri atas $8,3 \%$ gemuk dan $2,5 \%$ sangat gemuk (obesitas).

Kondisi anak di Indonesia sebanyak 8 dari 100 anak di Indonesia mengalami obesitas. Prevalensi kegemukan pada anak laki-laki umur 612 tahun lebih tinggi dari prevalensi dari anak perempuan yaitu berturutturut sebesar $10,7 \%$ dan $7,7 \%$ (Riskesdas 2013). Sedangkan di Kota Semarang, prevalensi obesitas pada anak sendiri meningkat dari 3,56\% pada tahun 2007 dan menjadi 3,8\% pada tahun 2011 (Riskesdas 2013). Berdasarkan Riset Kesehatan Dasar (Riskesdas) tahun 2015 dapat dilihat bahwa di Indonesia prevalensi obesitas berdasarkan Indeks Massa Tubuh (IMT) umur 6-12 tahun didapati pada anak laki-laki sebesar 10,7\% dan pada anak perempuan sebesar $7,7 \%$ (Depkes,2016). Sedangkan di Kabupaten Semarang, pada hasil penelitian Rizki Yulaeni, dkk (2015), bahwa di SD Mardirahayu Ungaran dari 64 responden didapatkan 39 responden $(60,9 \%)$ mengalami obesitas. Hasil Penelitian Dwi Purtiningsih,dkk (2017), bahwa di SD Mardi Rahayu siswa kelas IV-VI tahun ajaran 2016/2017 dari 71 siswa sebagai responden terdapat 22 siswa $(31,0 \%)$ yang mengalami obesitas.

Obesitas disebabkan oleh beberapa faktor yakni faktor genetik/keturunan, faktor pola makan, faktor status ekonomi sosial dan faktor aktivitas fisik. Faktor genetik sebenarnya menyumbang 10-30\%, sementara faktor perilaku dan lingkungan dapat mencapai $70 \%$. Salah satu faktor yang paling mempengaruhi terjadinya obesitas pada seseorang adalah aktivitas fisik. Perkembangan teknologi yang pesat berkontribusi pada peningkatan prevalensi kegemukan, tanpa disadari teknologi menggiring kita untuk bergaya hidup sedentary diantaranya kurang beraktifitas fisik, makan makanan instan, dan kurang mengkonsumsi buah dan sayur. Aktivitas fisik adalah setiap gerakan tubuh yang dihasilkan oleh otot rangka yang memerlukan pengeluaran energi. Aktivitas fisik yang tidak ada (kurangnya aktivitas fisik) merupakan faktor resiko independen untuk penyakit kronis, dan secara keseluruhan diperkirakan menyebabkan kematian secara global (Agus, 2013).

Aktivitas fisik pada anak membawa banyak manfaat yaitu bisa mengurangi risiko obesitas, penyakit pembuluh darah, dan keganasan. Ketrampilan gerak, interaksi social, dan perkembangan otak juga terasah saat bermain. Anak yang aktif akan belajar dengan lebih efektif, baik didalam maupun di luar lingkungan sekolah. Anak akan merasa gembira dan percaya diri, serta memiliki pola tidur yang baik. Aktivitas fisik yang dilakukan sejak dini akan membentuk anak menjadi seorang dewasa dengan gaya hidup aktif. (Sambo, 2013)

Aktivitas fisik pada anak-anak baik di sekolah maupun dirumah berperan penting dalam penentuan status gizi anak, termasuk resiko terjadinya obesitas. Aktivitas fisik merupakan gerakan tubuh dalam mengeluarkan energi. Aktivitas fisik dipengaruhi jenis, frekuensi dan waktu melakukan aktivitas. Semakin aktif seseorang melakukan aktivitas fisik, energy yang dibutuhkan semakin banyak. Pola aktivitas dapat dilihat dari bagaimana cara anak mengalokasikan waktunya selama 24 jam dalam kehidupan sehari-hari untuk melakukan suatu jenis kegiatan secara rutin dan berulang-ulang (WHO, 2011). 
Aktivitas fisik yang dilakukan secara teratur terus menerus sesuai umur dan kemampuan akan menurunkan berbagai resiko dan mencegah serta mengurangi lapisan lemak tubuh yang menyebabkan obesitas. Siswa yang melakukan aktivitas fisik ringan lebih beresiko 6,5 kali terkena obesitas dari pada siswa yang melakukan aktivitas fisik sedang (Smith, 2012, Guyton, 2014). Dengan melakukan aktivitas fisik yang sesuai dengan umur anak, diharapkan data yang signifikan terhadap Indeks Massa Tubuh (IMT) anak. Pada beberapa penelitian di Indonesia menunjukkan angka kejadian Obesitas pada anak sangat tinggi.Salah satu faktor yang berperan selain asupan makanan adalah aktivitas fisik. Untuk penilaian status gizi massa tubuh (IMT), karena penilaian dengan komponen tersebut dapat menentukan status gizi anak yang tergolong kelebihan berat badan maupun Obesitas. Pada Indeks Massa Tubuh (IMT) dipertimbangkan berat badan serta tinggi badan pada anak dan ditentukan oleh kurva tertentu (Almatsier, 2014).

Berdasarkan permasalahan di atas, maka penulis tertarik untuk mengetahui mengenai Hubungan antara Aktivitas Fisik dengan Kejadian Obesitas pada Anak sekolah di SD Mardi Rahayu Ungaran Kabupaten Semarang.

\section{METODE PENELITIAN}

Jenis penelitian ini adalah analitik dengan pendekatan cross sectional. Populasi dalam penelitian ini adalah anak usia sekolah yang bersekolah di SD Mardi Rahayu Ungaran dengan sampel 108 siswa yang diambil dengan cara purposive sampling. Data diperoleh melalui kuesioner PAQ-C (Physical Activity for Children) dan analisis data yang dilakukan secara univariat dan bivariat dengan menggunakan uji Chi-Square, menghasilkan distribusi frekuensi dan proporsi.

\section{HASIL PENELITIAN \\ Karakteristik Responden}

Tabel 1. Distribusi Frekuensi

Responden Berdasarkan Jenis

Kelamin Dan Umur Pada Siswa

Umur 8-12 Tahun Di SD Mardi

Rahayu Ungaran

\begin{tabular}{ccc}
\hline $\begin{array}{c}\text { Karakteristik } \\
\text { Responden }\end{array}$ & Frekuensi & $\begin{array}{c}\text { Persentase } \\
(\%)\end{array}$ \\
\hline 1. Jenis Kelamin & & \\
Laki-laki & 47 & 43,5 \\
Perempuan & 61 & 56,5 \\
\hline Total & 108 & 100,0 \\
\hline 2. Umur & & \\
8 & 29 & 26,9 \\
9 & 36 & 33,3 \\
10 & 21 & 19,4 \\
11 & 17 & 15,7 \\
12 & 5 & 4,6 \\
\hline Total & 108 & 100,0 \\
\hline
\end{tabular}

Berdasarkan tabel 1 dapat

diketahui bahwa responden yang berjenis kelamin laki-laki sebanyak 47 $(43,5 \%)$ dan responden yang berjenis kelamin perempuan sebanyak 61 (56,5\%). Pada penelitian ini jumlah responden perempuan lebih banyak dibandingkan dengan jumlah responden laki-laki. Dapat diketahui juga, bahwa responden paling banyak adalah umur 9 tahun yaitu $36(33,3 \%)$, umur 8 tahun sebanyak $29(26,9 \%)$ dan umur 10 tahun sebanyak $21(19,4 \%)$ responden.

\section{Analisis Univariat}

Analisis univariat ini dilakukan untuk melihat distribusi frekuensi dan presentase aktivitas fisik dan kejadian obesitas pada siswa berumur 8-12 tahun di SD Mardi Rahayu Ungaran.

\section{Aktivitas Fisik}


responden mempunyai aktivitas fisik ringan.

Responden yang mempunyai aktivitas fisik dalam kategori ringan, yaitu sebesar 34,3\% (37 responden). Aktivitas fisik dalam kategori ringan dalam penelitian ini dapat dilihat dari hasil penelitian yang diukur selama 7 hari terakhir sebelum dilakukan penelitian dimana sebagian besar yaitu sebanyak $35 \%$ responden hanya melakukan 1-2 kali salah satu kegiatan seperti melompat (bermain tali), bersepeda, lari/jogging, sepakbola dan kegiatan lainnya yang sering dilakukan oleh anak seumuran mereka. Selain itu $21,3 \%$ responden juga menyatakan bahwa mereka tidak pernah melakukan olahraga, menari, bermain kejar-kejaran atau bermain permainan dengan sangat aktif (berkeringat) setelah pulang sekolah. Sedangkan pada saat sore hari dalam $23,1 \%$ responden menyatakan bahwa mereka tidak pernah melakukan olahraga. Dan 26,9\% responden menyatakan bahwa mereka melakukan aktivitas fisik di waktu luang hnya 1-2 kali dalam seminggu. Beberapa hal tersebut menunjukkan kurangnya aktivitas fisik yang dilakukan oleh sebagian besar anak dalam 7 hari terakhir di rumah sehingga dapat disimpulkan bahwa sebagian besar responden mempunyai aktivitas fisik dalam kategori ringan.

Aktivitas fisik dalam kategori ringan pada sebagian besar anak juga dapat dilihat dari beberapa jenis kegiatan yang dilakukan oleh anak saat berada di lingkungan sekolah dimana didapatkan data bahwa sebagian besar responden menyatakan bahwa kegiatan yang sering mereka lakukan dalam 7 hari terakhir ini saat jam istirahat hanya duduk (berbicara, membaca, mengerjakan tugas sekolah) sebanyak $35,2 \%$ responden, selain itu, selama pelajaran olahraga sebagian besar anak kadang-kadang aktif dalam bermain, berlari, melompat, dlln sebanyak 13,9\% responden. Beberapa hal tersebut juga menunjukkan kurang aktifnya aktivitas fisik yang dilakukan oleh sebagian besar anak saat berada di sekolah maupun lingkungan di sekolah sehingga dapat disimpulkan bahwa sebagian besar anak mempunyai aktivitas fisik dalam kategori ringan.

Aktivitas fisik ringan adalah kegiatan yang dilakukan hanya memerlukan sedikit tenaga dan biasanya tidak menyebabkan perubahan dalam pernapasan atau kesehatan (endurance). Rendahnya aktivitas fisik pada sebagian besar anak dalam penelitian ini menurut peneliti dikarenakan oleh adanya teknologi yang berkembang saat ini, dimana pada saat ini banyak berbagai jenis permainan yang disediakan diberbagai layanan media online sehingga memudahkan anak-anak untuk mengaksesnya dan memainkannya. Hal tersebut juga ditunjang oleh banyaknya anak yang sudah memakai dan menggunakan gadget (handphone android) sehingga memudahkan mereka untuk memainkan beragam permainan yang ada dan tersedia dari berbagai fitur baik secara online maupun offline. Hal tersebut menyebabkan salah satu kurangnya aktivitas fisik pada sebagian besar anak saat ini karena mereka dapat melakukan berbagai permainan tanpa beranjak dari tempat duduk mereka dan tanpa melakukan aktivitas fisik yang berlebih seperti berlari, melompat, dan lain sebagainya.

Dalam International Journal of Obesity yang berjudul Physical activity and obesity in children menyatakan bahwa aktivitas fisik memainkan peran penting dalam pencegahan kelebihan berat badan dan obesitas pada masa kanak-kanak dan remaja, dan mengurangi obesitas di masa dewasa (Hills, 2011). Hasil penelitian tersebut didukung oleh penelitian yang dilakukan Lolita (2013), hasil penelitian 
didapatkan 73,5\% anak SD yang memiliki intensitas aktivitas ringan.

Pola aktivitas fisik anak masa kini telah mengalami pergeseran dari zaman dulu yang lebih banyak bergerak menjadi lebih sedikit beraktivitas fisik. Sebagai contoh, dulu sering ditemu anak-anak bermain bola, petak umpet, atau lompat tali. Pada saat ini lebih banyak terlihat anak-anak berada di Warung Internet (WarNet) untuk bermain game online, atau pada keluarga yang mampu, anak-anak berada di depan computer atau bermain dengan gadget canggih pada waktu luangnya (Sartika,2011).

Hasil penelitian tersebut didukung oleh penelitian Wisnu (2017) dimana didapatkan hasil penelitian pada anak usia 7-12 tahun di SD Kristen Petra Jombang bahwa sebagian besar responden yang aktivitas fisiknya kurang sejumlah 29 orang $(67,4 \%)$. Hal tersebut dapat terjadi karena anak usia ini lebih senang berada di dalam rumah dengan menonton televisi, bermain video games, bermain playstation daripada melakukan aktivitas diluar rumah seperti bersepeda, basket, voli, badminton. Orang tua saat ini kurang percaya atau kurang merasa aman apabila anaknya bermain diluar rumah atau bermain dengan teman sebayanya. Orang tua juga kurang meluangkan waktu untuk menghabiskan waktu bersama anak dengan bermain bersama anak, melakukan olahraga bersama, atau kegiatan lain yang lebih membutuhkan pengeluaran energi.

Responden dalam kategori aktivitas fisik berat sebanyak $9(8,3 \%)$ responden. Aktivitas fisik anak sekolah dasar yang dianjurkan adalah aktivitas fisik dengan intensitas sedang dan dilakukan secara teratur. Tetapi aktivitas fisik berat atau berlebihan juga akan membuat daya tahan tubuh anak yang masih labil, mudah terkena penyakit. Dan penyakit itu juga berdampak buruk pada pertumbuhan anak. Apalagi penyakit yang bersifat infeksi. Jika sedari kecil anak usia sekolah dasar diberikan aktivitas fisik yang kompleks, hal itu akan menghambat pertumbuhan. Dengan aktivitas fisik yang berat, maka hal itu akan membuat otot membesar bersamaan dengan pertumbuhan tulang akan berdampak buruk bagi si anak.

Berdasarkan hasil penelitian dapat diketahui bahwa responden yang mengalami obesitas sebanyak 35,2\% (28 responden), sedangkan yang tidak obesitas yaitu sejumlah $64,8 \% \quad(70$ responden). Dapat disimpulkan bahwa responden yang obesitas lebih sedikit, namun kejadian obesitas di SD Mardi Rahayu termasuk tinggi.

Obesitas masih merupakan masalah kesehatan bagi anak maupun dewasa, oleh karena komplikasi jangka pendek obesitas itu sendiriberakibat terhadap pertumbuhan tulang, penyakit endokrin, kardiovaskular, dan system gastrointestinal. Pada anak sekolah, kejadian kegemukan dan obesitas merupakan masalah yang serius karena akan berlanjut hingga usia dewasa. Pada anak, kegemukan dan obesitas dapat mengakibatkan berbagai masalah kesehatan yang sangat merugikan kualitas hidup anak seperti gangguan pertumbuhan tungkai kaki, gangguan tidur,sleep apnea (berhenti napas sesaat) dan gangguan pernapasan lain (Depkes, 2012).

Di Indonesia, kasus terbaru tentang obesitas pada seseorang dengan berat badan $300 \mathrm{~kg}$ menyebabkan kesulitan beraktvitas. Berat badannya menjadi seperti ini disebabkan karena pola makan yang berlebihan tetapi tidak pernah melakukan aktivitas fisik. (Kurnia,2019)

Dalam buku Obesitas pada Anak, Komite Keselamatan Makanan, Kesehatan Masyarakat, dan Lingkungan Hidup di Parlemen Eropa menyatakan 
bahwa hampir 22 juta anak di Eropa mengalami kegemukan dan obesitas, jumlah ini diperkirakan akan terus bertambah sebanyak 1,3juta pada tahun 2010. Dalam Prevalence of Obesity and Severe Obesity in US Children 19992016 (2018) menyatakan bahwa anakanak menunjukkan peningkatan tajam dalam prevalensi obesitas dari 20152016. Penelitian Nicholas dan kawankawan yang dimuat dalam Nutritional Journal 2005 bahkan menyebutkan bahwa saat ini anak penderita kegemukan di Amerika Serikat mencapai $25 \%$ sedangkan penderita obesitas sebesar 11\%. Mengutip data Riset Kesehatan Dasar Kementrian Kesehatan Republik Indonesia pada 2013, secara nasional masalah gemuk pada anak usia 5-12 tahun masih tinggi yakni $18,8 \%$ terdiri atas gemuk $10,8 \%$ dan sangat gemuk (obesitas) $8,8 \%$.

Pada hasil penelitian ini yang mengalami obesitas lebih banyak yaitu berjenis kelamin laki-laki yaitu sebanyak 42,6\% (20 responden) dan perempuan sebanyak $29,5 \% \quad(18$ responden). Hal ini sesuai dengan Riskesdas (2013) bahwa prevalensi kegemukan pada anak laki-laki umur 612 tahun lebih tinggi dari prevalensi anak perempuan. Kondisi anak di Indonesia sebanyak 8 dari 100 anak di Indonesia mengalami obesitas. Sedangkan di Kota Semarang, prevalensi obesitas pada anak sendiri meningkat dari 3,56\% pada tahun 2007 dan menjadi 3,8\% pada tahun 2011 (Riskesdas 2013). Berdasarkan Riset Kesehatan Dasar (Riskesdas) tahun 2015 dapat dilihat bahwa di Indonesia prevalensi obesitas berdasarkan Indeks Massa Tubuh (IMT) umur 6-12 tahun didapati pada anak laki-laki sebesar $10,7 \%$ dan pada anak perempuan sebesar 7,7\%. Sedangkan di Kabupaten Semarang, pada hasil penelitian Rizki Yulaeni, dkk (2015), bahwa di SD Mardirahayu Ungaran dari 64 responden didapatkan 39 responden $(60,9 \%)$ mengalami obesitas. Hasil Penelitian Dwi Purtiningsih,dkk (2017), bahwa di SD Mardi Rahayu siswa kelas IV-VI tahun ajaran 2016/2017 dari 71 siswa sebagai responden terdapat 22 siswa $(31,0 \%)$ yang mengalami obesitas. Dari data penelitian tersebut dapat terlihat bahwa kejadian obesitas mengalami peningkatan dari tahun 2017 sebanyak $31,0 \%$ menjadi $35,2 \%$ pada tahun 2019.

Kesejahteraan yang meningkat dan berubahnya pola makan masyarakat mengakibatkan peningkatan konsumsi lemak oleh masyarakat. Berkurangnya lapangan tempat bermain serta semakin tersedianya hiburan dalam bentuk tontonan televisi, permainan video atau playstation menyebabkan berkurangnya aktivitas fisik terutama oleh anak-anak (Jhon,2010).

Obesitas terjadi sebagai akibat adanya ketidakseimbangan antara jumlah energi yang masuk dengan yang dibutuhkan oleh tubuh untuk berbagai fungsi biologis seperti pertumbuhan fisik, perkembangan aktivitas, pemeliharaan kesehatan. Beberapa faktor penyebab obesitas pada anakanak antara lain asupan makan berlebih yang berasal dari jenis makanan olahan serba instan, minuman soft drink, dan makanan jajanan seperti makanan cepat saji lainnya (Almatsier,2001).

Berdasarkan uraian diatas menunjukkan bahwa banyak faktor yang melatarbelakangi dan menjadi penyebab terjadinya obesitas pada sebagian besar anak khususnya yang bersekolah di SD Mardi Rahayu Ungaran Kabupaten Semarang diantaranya banyaknya jajanan di sekitar lingkungan SD, kurangnya aktivitas fisik anak dan lain sebagainya. Hal tersebut diperkuat oleh hasil pengamatan peneliti selama penelitian ini berlangsung dimana saat penelitian tersebut peneliti melakukan pengamatan 
terhadap responden dan lingkungan dimana saat penelitian ini berlangsung. Berdasarkan hasil observasi dan pengamatan tersebut didapatkan data bahwa sebagian besar anak hanya duduk-duduk dan bercanda dengan teman nya, Ada juga anak-anak yang bermain handphone dan berdiam diri didalam kelas. Serta ada anak yang mengakui hanya menonton Televisi dan bermain game pada saat dirumah. Hal tersebut menurut peneliti merupakan salah satu penyebab terjadinya obesitas pada sebagian besar responden karena kurangnya aktivitas fisik saat jam istirahat belajar.

Masa kanak-kanak identik dengan masa bermain, permainan anak pada masa dulu umumnya adalah permainan fisik yang mengharuskan anak berlari, melompat, atau gerakan lainnya. Tetapi, hal itu telah tergantikan dengan game elektronik, komputer, internet, atau televisi yang cukup dilakukan dengan hanya duduk didepannya tanpa bergerak-gerak. Hal inilah yang menyebabkan anak kurang melakukan gerak badan sehingga menyebabkan kelebihan berat badan (Sartika, 2011).

Berdasarkan hasil pengamatan peneliti juga didapatkan data bahwa sebagian besar anak saat jam istirahat tidak melakukan aktivitas fisik, mereka hanya duduk-duduk di sekitar lingkungan kelas sambil makan makanan ringan yang dibeli di kantin sekolah mereka dan terdapat beberapa anak yang sedang makan makanan yang dibawa dari rumah sebagai bekal mereka. Sebagian besar anak dalam penelitian ini dalam pengamatan peneliti cenderung mengkonsumsi jenis makanan fast food dan makanan berkalori tinggi lainnya seperti sosis, nugget, tempura dan sedikit siswa yang mengkonsumsi sayur dan buah.

Berdasarkan hasil penelitian diketahui bahwa responden yang obesitas dengan kategori aktivitas fisik ringan yaitu $67,6 \%$ lebih tinggi dibandingkan dengan responden dengan aktivitas fisik sedang sebanyak 19,4\% dan aktivitas fisik berat sebanyak $11,1 \%$. Hal ini menunjukkan bahwa semakin ringan aktivitas yang dilakukan maka semakin tinggi resiko terjadinya obesitas.

Kecenderungan sekarang, aktivitas fisik menurun dikarenakan gaya hidup modern yang menyebabkan status gizi anak diatas normal, sehingga anak menjadi gemuk atau obesitas. Hal ini disebabkan karnea anak-anak banyak makan namun kurang beraktivitas sehingga energi yang masuk ke dalam tubuh jauh lebih banyak daripada energi yang digunakan untuk beraktivitas dan pertumbuhan (Misnadiarly,2009).

Aktivitas fisik memberikan keuntungan bagi kesehatan tubuh. Aktivitas fisik khususnya olahraga dapat meningkatkan efisiensi miokardinal melalui peningkatan aliran darah dan oksigen untuk memenuhi metabolism lokal. Aktivitas fisik juga menurunkan risiko terjadinya resistensi insulin, intoleransi glukosa, hiperglikemia post prandial, dan gluconeogenesis hepatic. Aktivitas fisik diketahui memegang peranan penting terhadap distribusi lemak tubuh melalui penggunaan lemak dari daerah perut sebagai hasil redistribusi jaringan adipose. Aktivitas fisik yang tidak adekuat menyebabkan semakin besarnya lemak tubuh yang ditimbun pada jaringan. Aktivitas fisik yang ringan menyebabkan keluaran energi menjadi rendah sehingga terjadi ketidakseimbangan antara masukan energi yang lebih banyak dibandingkan dengan energi yang keluar. Akibat dari sedikitnya energi yang keluar dari tubuh, maka sisa dari energi tersebut akan tersimpan menjadi lemak dan kemudian menjadi overweight hingga 
berlanjut menjadi obesitas (Syarif, 2010).

Aktivitas fisik yang dilakukan secara teratur akan menurunkan risiko obesitas dan penyakit degenerative lainnya seperti hipertensi, penyakit jantung, diabetes mellitus, osteoporosis, kanker dan sebagainya. Hasil penelitian yang dilakukan Boone (2009) menemukan bahwa aktivitas fisik pada anak usia SMP dan SMA penting untuk pembentukan kebiasaan seumur hidup serta untuk jangka pendek adalah pada pemantauan berat badan. Penelitian ini juga menyimpulkan bahwa mengurangi waktu anak di depan tekevisi/Komputer/PS dapat menjadi strategi untuk mengurangi kejadian obesitas terutama pada wanita (Boone, 2009).

Berdasarkan hasil analisis statistik dengan menggunakan uji ChiSquare didapatkan nilai $\mathrm{p}=0,000$. Oleh karena nilai $\mathrm{p}<0,05$ maka dapat disimpulkan bahwa ada hubungan antara aktivitas fisik dengan kejadian obesitas pada anak sekolah di SD Mardi Rahayu Ungaran.

Hasil penelitian tersebut
didukung oleh penelitian yang dilakukan Lolita (2013), bahwa didapatkan $100(73,5 \%)$ anak SD yang memiliki intensitas aktivitas ringan terdapat $58 \quad(85,3 \%)$ anak yang mengalami obesitas. Besarnya pengaruh aktivitas fisik ringan terhadap obesitas anak ditunjukkan nilai OR $=3,59(95 \%$ CI:1,565-8,238). Artinya anak yang mempunyai aktivitas fisik ringan memiliki risiko lebih besar 3 kali menjadi obes dibandingkan dengan anak yang memiliki aktivitas fisik sedang atau berat. Hasil penelitian ini juga sesuai dengan penelitian dari Aan Fitriyan, dkk (2017) di SD Negeri 2 Redin, Gebang, Purworejo, bahwa dari 79 siswa/siswi terdapat 28 siswa/siswi yang mengalami obesitas, 25 siswa/siswi $(31,6 \%)$ mengalami obesitas dengan aktivitas fisik ringan, dan 3 siswa/siswi $(10,7 \%)$ mengalami obesitas dengan aktivitas sedang.

Hasil penelitian ini sesuai dengan penelitian Ni Made Ayu (2018) terhadap 20 responden, pada kelompok obesitas sebagian besar anak memiliki aktivitas fisik yang kurang yaitu sebanyak 18 orang $(90 \%)$. Berdasarkan kenyataan yang terjadi di lapangan hal ini disebabkan karena sebagian besar anak dengan obesitas lebih banyak menghabiskan waktu mereka dengan menonton televisi atau bermain gadget dan jarang berolahraga. Hal ini dibuktikan dari hasil penelitian yang telah dilakukan dimana menyatakan bahwa sebagian besar responden tidak pernah bermain voli, basket, kasti, menari, sepak bola, dan bulu tangkis. Hasil penelitian juga menyatakan bahwa sebagian besar responden sering dudukduduk ketika waktu istirahat dan saat jam makan siang. Pendapat ini didukung oleh Gavin (2005 dalam Musadat, 2010) yang menyatakan bahwa anak yang menonton televisi lebih dari 4 jam dalam sehari lebih mudah terkena obesitas dari pada anak yang menonton televisi hanya 2 jam per hari.

Hal ini sejalan dengan penelitian yang dilakukan oleh Octari dkk. (2013) dengan hasil penelitian sebagian besar siswa dengan obesitas memiliki aktivitas fisik yang kurang aktif yaitu sebanyak 21 orang $(26,92 \%)$ dan pada kelompok anak yang tidak obesitas sebagian besar anak memiliki aktivitas fisik yang aktif yaitu sebanyak 99 orang $(84,62 \%)$. Penelitian lain yang sejalan dengan penelitian ini adalah penelitian yang dilakukan oleh Danari dkk. (2013) dengan hasil sebagian besar anak obesitas memiliki aktivitas fisik ringan yaitu sebanyak 58 anak $(85,3 \%)$.

Pola aktivitas fisik yang minim berperan besar dalam peningkatan risiko kegemukan dan obesitas pada anak. 
Sebagaimana telah dikemukakan sebelumnya, kegemukan dan obesitas lebih mudah diderita oleh anak yang kurang beraktivitas fisik maupun olahraga. Kegemukan dan obesitas pada anak yang kurang beraktivitas fisik maupun berolahraga disebabkan oleh jumlah kalori yang diperoleh dari makanan yang dikonsumsi sehingga berpotensi menimbulkan lemak berlebih dalam tubuh.

\section{PENUTUP}

\section{Kesimpulan}

Berdasarkan hasil penelitian yang telah dilakukan, dapat disimpulkan beberapa hal sebagai berikut :

1. Responden yang mempunyai aktivitas fisik dalam kategori ringan yaitu sejumlah $37 \quad(34,3 \%)$ responden, sedangkan responden dengan aktivitas fisik dalam kategori sedang yaitu sejumlah 62 $(57,4 \%)$ responden, dan responden dengan aktivitas fisik berat sejumlah $9(8,3 \%)$ responden.

2. Responden yang mengalami Obesitas sebanyak 38 responden $(35,2 \%)$, sedangkan yang Tidak Obesitas yaitu sejumlah 70 responden $(64,8 \%)$.

3. Ada hubungan antara aktivitas fisik dengan kejadian obesitas pada anak sekolah di SD Mardi Rahayu Ungaran $(p=0,000)$

\section{Saran}

Hasil penelitian ini dapat dijadikan masukan bagi Pihak Sekolah SD Mardi Rahayu Ungaran agar mengadakan program tambahan berupa aktivitas fisik yang bersifat aerobik (lari,renang) dengan intensitas sedang (3x seminggu) dan dilakukan dengan ritmis (teratur). Dari hasil penelitian ini diharapkan ada penelitian lanjutan untuk mengetahui hubungan aktivitas fisik dengan kejadian obesitas dengan cara pengukuran yang berbeda (intensitas, lama, dan jenis).

\section{DAFTAR PUSTAKA}

Aan Fitriyan. (2017). Hubungan Aktivitas Fisik dengan Kejadian Obesitas Pada Anak di SD Negeri 2 Redin Gebang Purworejo.Skripsi. Yogyakarta: Stikes Jendral Ahmad Yani Yogyakarta.

Angraini, DS. (2014). Hubungan Depresi dengan Status Gizi.Journal Content Vol.2.No.02.diakses pada tanggal 9 maret 2019.. dari:http://juke.kedokteran.unil a.ac.if/index.php/medulla/articl e/view.

Artikah,P. (2010). Obesitas Dan Penggunaan Perilaku Makan Pada Remaja.Yogjakarta : CV Nuha Medika.

American Occupational Therapy Association. 2013. Obesity and Occupational Therapy. American Journal of Occupational Therapy. Diakses pada tanggal 9 Maret 2019.

Boone. (2009). Screen time and physical activity during adolescence : longitudinal effects on obesity in young adulthood. International journal of Behavioral Nutrition and Physical Activity 10,pp. 110.

Budiyanti. (2011). Analisis Faktor Penyebab Obesitas pada Anak Usia Sekolah di SD Islam AlAzhar 14 Kota Semarang. FIK UI. Diakses pada tanggal 10 April 2019. 
Chou YC \& Pei JS. (2010).Risk Factor of Adolescent Obesity in Taiwan and Its Association with Physical Activity, Blood Pressure, and waist Circumreference.Asian Journal og Sport medicine.Diakses pada tanggal 9 Maret 2019.

Danari, A. L., Mayulu, N., Onibala, F. (2013). Hubungan aktivitas fisik dengan kejadian obesitas pada anak sd di Kota Manado. Dari https://ejournal.unsrat.ac.id/ind ex.php/jkp/article/view/2162

Dewi, Ade Chintya Nirmala, (2013). Hubungan Pola Makan, Aktivitas fisik,Sikap, Dan Pengetahuan Tentang Obesitas demgan Status Giz Pegawai Negri Sipil Di Kantor Dinas Kesehatan Provinsi Jawa Timur. Surabaya : Media Gizi Indonesia.Diakses pada tanggal 9 Maret 2019.

Dinkes Prov. Jateng. (2014). Profil Kesehatan Provinsi Jawa Tengah. Semarang.

Dinkes Prov. Jateng. (2015). Profil Kesehatan Provinsi Jawa Tengah. Semarang.

Dinkes Prov. Jateng. (2016). Profil Kesehatan Provinsi Jawa Tengah. Semarang.

Fariha, Dela. (2016). Pengaruh Obesitas Terhadap Kebugaran Pada Anak Sekolah Dasar Usia 10-12 Tahun.Skripsi.

Ginanjar, Wahyu.(2009).Obesitas Pada Anak . Bandung: Mizan. 2009
Hasdianah . (2016). Patologi dan patofisiologi penyakit. Yogyakarta: Penerbit Nuha Medika.

Hidayah. (2014). Perilaku pada Anak Usia Sekolah, Bentang pustaka, Bandung.

Hills, et all. (2011). Physical Activity and obesity in Children. British Journal of Sports Medicine. Australia

Huh, Susanna Y. "Pediatrics Risiko Obesitas" dalam Mediaupdate. Edisi April 2011. h. 48. Diakses pada tanggal 15 Maret 2019.

Kemenkes, RI. (2011). Riset Kesehatan Dasar2014. Jakarta: Badan Penelitian dan Pengembangan Kesehatan Kemenkes RI.Diakses pada tanggal 20 Maret 2019.

Kemenkes, RI. (2012). Pedoman Pencegahan dan Penanggulangan Kegemukan dan Obesitas pada Anak Sekolah.

Dari:http://www.gizi.depkes.go .id/download/Pedoman\%20Giz i/Obesitas.pdf. Diakses pada tanggal 20 Maret 2019.

Kompas. (2019).Titi Wati Si Penderita Obesitas akhirnya tahu bootnya bukan 300kg. darihttps://www.google.com/a $\mathrm{mp} / \mathrm{s} / \mathrm{amp}$. kompas.com/regiona 1/read/2019/01/14/17195121/tit i-wati-si-penderita-obesitasakhirnya-tahu-bobotnyabukan-300-kg

Kunkun, K. (2009). Obesitas; Permasalahan dan Terapi 
Praktis.Jakarta : CV Sagung Setyo.

Lee, et al. (2003)."Frequency of Instant Noodle (Ramyeon) Intake and Food Value Recognition and Their Relationship to Blood Lipid Lecels of Male Adolescent in Rural Area". Korean Journal of Community Nutrition Agustus 2003;8(4) : 485-489.

Lolita, Angel. (2013). Hubungan Aktivitas Fisik dengan Kejadian Obesitas pada Anak SD di Kota Manado. Jurnal Keperawatan Vol. 1, No.1(1).

Maharani. (2015). Hubungan Kebiasaan Makan, Aktivitas Fisik dan tingkat stress dengan Obesitas pada remaja di Semen Padang. Diploma thesis.UPT.Perpustakaan Unand.Dari scholar.unand.ac.id/339/.

Musadat, A. (2010). Analisis faktorfaktor yang mempengaruhi kegemukan pada anak usia 614 tahun di Provinsi Su-matera Selatan. [Tesis]. Bogor: Institut Pertanian Bogor.

Ni Made, dkk. (2018). Hubungan Aktivitas fisik, pola makan, dan pendapatan orang tua dengan kejadian obesitas pada anak sekolah dasar. Sekolah tinggi ilmu kesehatan : Bali.

Purtiningsih, Dwi dkk. (2017). Hubungan antara pola makan dengan kejadian Obesitas pada anak usia sekolah dasar di SD Mardi Rahayu Ungaran.Skripsi.Ungaran Universitas Ngudi Waluyo.
Sambo. (2013). Aktivitas pada Anak. Bandung: Bentang Pustaka.

Sartika, RAD. (2011). Faktor Resiko Obesitas Pada anak 5-15 tahun di Indonesia. Jakarta: Universitas Indonesia. Makra, Kesehatan

Vol.15.N0.1.Diakses pada tanggal 20 Maret 2019.

Sastroasmoro, Sudigdo dan Sofyan Ismael. (2014). Dasar-Dasar Metodologi Penelitian Klinis Edisi Ke-5. Jakarta: Sagung Seto. Diakses pada tanggal 20 Maret 2019.

Soegondo. (2005). Diagnosis ddan Klasifikasi Diabetes Mellitus Terpadu. Balai Penerbit FK UI. Jakarta.

Suastika, K. (2011). Obesitas dan Diabetes.Denpasar : Udayana Iniversity Press.Diakses pada tanggal 20 Maret 2019.

Supariasa IDN, dkk. (2014). Penilaian Status Gizi.EGC : Jakarta.

Sutanto. 2010. Cekal penyakit modern Hipertensi, Stroke, Jantung, Kolesterol, dan Diabetes. Yogyakarta: CV. Andi Offset.

WHO.(2013),Overweight/obesity.http:// www.who.int/infobase.Diaks es pada tanggal 20 Maret 2019.

World Health Organization Media Centre. (2015), Obesity and Overweigt fact sheet.http://www.who.int/info base. Diakses pada tanggal 20 Maret 2019.

World Health Organizarion Media Centre. (2016). "Physical 
Actovity"/ diambil dari http://www.who.int/topics/ph physic_activity/en/.

Yulaeni, Rizki. (2015). Hubungan Antara Pola Makan dengan Kejadian Obesitas pada anak usia 7-12 tahun di SD Mardi Rahayu Ungaran Kabupaten Semarang dari http://perpusnwu.web.id.

Zamzani, M dkk. (2016). Aktivitas fisik yang berhubungan dengan kejadian obesitas pada Anak sekolah dasar. Jurnal Gizi dan Dietik Indonesia. Vol. 4, No. 3, September 2016: 123-128. 